\section{ОРГАНІЗАЦІЯ КРУЇЗНИХ ПЕРЕВЕЗЕНЬ В УМОВАХ ПАНДЕМIÏ COVID-19}

\section{ORGANIZATION OF CRUISE IN THE CONVENTION OF THE COVID-19 PANDEMIC}

\author{
GURENKO A., \\ $\mathrm{PhD}$ in Economics, Associate \\ Professor of the Department of \\ "Management and \\ Entrepreneurship in Maritime \\ Transport", \\ OCHEREDKO O., \\ Senior Lecturer, Azov Maritime \\ Institute National University \\ "Odessa Maritime Academy"
}

У статті проаналізовано організація круїзних перевезень та існуючі проблеми і перспективи розвитку круїзних перевезень в умовах пандеміï Covid-19. На сучасному етапі розвитку $\epsilon$ необхідність підтримки та удосконалення механізмів державного та міжнародного регулювання діяльності та організації круїзних перевезень. Від ефективної організації круїзних перевезень в умовах пандемії Covid-19 залежить розвиток круїзних перевезень в цілому.

Ключові слова: організація, круїзні перевезення, пандемія Covid-19.

В статье проанализирована организация круизных перевозок, существующие проблемы и перспективы развития круизных перевозок в условиях пандемии Covid-19. На современном этапе развития существует необходимость поддержки и совершенствования механизмов государственного и международного регулирования деятельности и организации круизных перевозок. От эффективной организации круизных перевозок в условиях пандемии Covid-19 зависит развитие круизных перевозок в целом.

Ключевые слова: организация, круизные перевозки, пандемия Covid-19.

In this article, we analyzed the organization of cruise traffic and existing problems and prospects for the development of cruise traffic in conditions of the pandemic Covid-19. At the present stage of development, there is a need to support and improve the mechanisms of state and international regulations of activities and the organization of cruises. The development of cruises, in general, depends on the effective organization of cruises in the conditions of the Covid-19 pandemic.

Keywords: organization, cruises, pandemic Covid-19.

Постановка проблеми. Організація круїзних перевезень в умовах пандеміï Covid-19 засноване на обліку принципових положень і закономірностей оптимізації діяльності в системі суперечливих міжнародних ринкових обмежень. Проблема ефективної організації 
виникає з формуванням конкурентних технологій і альтернативного їх використання в умовах обмеженості ресурсів і попиту.

Аналіз останніх досліджень і публікацій. Теоретичним і практичним аспектам організації круїзних перевезень в міжнародному туризмі, географії круїзних маршрутів займалися наступні науковці: Александрова А., Біржаков М., Надточій В. та інші. Стан та перспективи розвитку круїзного туризму у світі та Україні

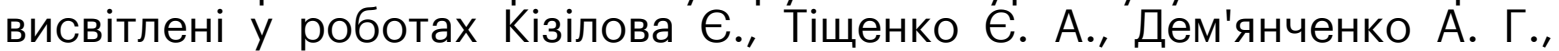
Соловйов А. А., А. О. Филипенко, Мельник І. Л. та ін.

Метою статті $\epsilon$ організація круїзних перевезень в умовах пандеміï Covid-19 за принципами міжнародного управління та регулювання.

Виклад основного матеріалу дослідження. Через обмеження, пов'язані з пандемією Covid-19, літній сезон 2020 року виявився дуже непривабливим для туристичних галузей - в тому числі круїзних підприємств. Попередній сезон 2019 року видався вдалим для операторів міжнародних морських перевезень. В цьому ж році коронавірус завдав серйозного удару по галузі. Сезон не відкритий дотепер і майбутні перспективи вельми туманні. В даний час вся туристична індустрія в світі знаходиться в стані глибокої кризи через пандемію Covid-19. Світове круїзне судноплавство відчуває найбільший і безпрецедентна криза з часів Другої світової війни. Саме це, в свою чергу, веде до рекордно низьких цін на вторинному ринку пасажирських суден.

Зокрема упродовж декількох десятиліть ринок морських круїзів демонстрував помітне збільшення та стабільний приріст. На міжнародному круїзному ринку відбувалась дуже висока концентрація флоту небагатьох круїзних підприємств, які мали майже 85\% ринку круїзних послуг. Їх представництва розташовані у всіх країнах світу [2]. Потрібно більш детально висвітлити основні показники та сучасні тенденції організації круїзних перевезень.

Весь світовий круїзний флот, понад 320 круїзних суден місткістю 550 тис. пасажирів припинив роботу і встав на відстій до квітня 2020 року. Бізнес, орієнтований на 27 млн круїзних туристів в рік, припинився протягом трьох місяців після початку пандемії у всіх портах світу.

Треба окремо відзначити, що в останні 10 років круїзне судноплавство в світі розвивалося небувалими темпами. Відбувався ріст тоннажу круїзних суден і стрімко будувався новий флот. В період до 2025 року заплановано будівництво ще понад 50 круїзних суден для провідних світових брендів, а загальна місткість круїзного флоту, відповідно, мала б зрости майже вдвічі і досягти 1 млн пасажирів [1].

Але, пандемія Covid-19 стала справжнім шоком для круїзних операторів, оскільки ця криза не має аналогів в історії судноплавства останні 70 років за своїми глобальними наслідками.

Отже, наприклад, терористичний напад на США у 2001 році призвів до зниження круїзного судноплавства за межами американського ринку на 30-40\%, епідемії SARS у 2003 році і свинячого грипу у 2008 році в Китаї практично не зробили впливу на роботу галузі та в основних регіонах судноплавства.

На даний час більшість глобальних круїзних операторів належать компаніям з США (приблизно 85\% світового флоту (Carnival Corporation PLC, Royal Caribbean International, NCL Cruise Holding) [2]. Виняток становлять компанія MSC Cruises i ряд невеликих 
регіональних операторів, які зареєстровані в Європі. 3 появою нового вірусу Covid-19 влада США в травні 2020 роки заборонила круїзним компаніям приймати пасажирів до перевезення з портів США, що призвело до постановки всього флоту на прикол.

Через пандемію круїзні компанії змушені зазнавати величезні збитки, судна стоять 3 екіпажами в різних портах світу, їх обслуговування та постачання обходиться в сотні тисяч доларів в місяць. Більшість нових судів побудовані на кредитні кошти банків, що призводить до мультиплікативного ефекту в частині збільшення витрат при повній відсутності виручки.

Зазначимо, що відповідно договору морського круїзу одна сторона - організатор круїзу зобов'язується здійснити колективну морську подорож (круїз) за визначеною програмою і надати усім учасникам круїзу необхідні послуги (морське перевезення, харчування, екскурсійне обслуговування побутове та тощо), а інша сторона - учасник круїзу повинен сплатити за це певну плату [3].

Документ, який підтверджує наявність договору морського круїзу, $є$ іменна путівка або інший оформлений у встановленому порядку документ до неї, виданий організатором круїзного перевезення.

Перш за все, учасники круїзного перевезення мають право у будь-який час до початку круїзу надати відмову від договору морського круїзу. Будь-який учасник круїзу, який заздалегідь повідомив організатора круїзу про відмову від договору, має право отримати назад плату за подорож у порядку, розмірах і терміни, які встановлені договором морського круїзу [3].

У випадку, коли організатор круїзу не може надати учасникові круїзу місце на судні, яке передбачено договором, або за згодою учасника круїзу таке ж місце на іншому судні, що за своїми характеристиками і комфортабельністю не нижче обумовленого, учасник круїзу вправі відмовитися від договору і повністю отримати назад плату за круїз.

До Кодексу торговельного мореплавства України положення, що присвячені морському круїзу внесені вперше. В тому числі, вперше на законодавчому рівні відповідно до ст. 195 КТМ України визначає поняття договору морського круїзу [3].

Розрізняють наступні види круїзних перевезень: туристські, коли тривалість поїздки становить більше 24 годин; екскурсійнопрогулянкові, коли тривалість поїздки становить менше 24 годин. Такі рейси здійснюються 3 метою відпочинку та ознайомлення 3 історичними та іншими пам'ятками, як правило, між двома портами 3 заходами та зупинками в них або без заходів і зупинок.

Отже, організаторами круїзу можуть виступати як безпосередньо судновласник - перевізник, так і відповідна організація, що проводить круїз на відповідній туристській лінії. Організатор круїзу укладає з перевізником договір про організацію круїзів, в тому числі на умовах фрахтування судна або на проїзд окремої групи відпочиваючих пасажирів.

На сьогодні символом круїзного флоту стали комфорт і комплексність обслуговування туристів. На суднах рівень забезпечення туристів різноманітними послугами може бути порівняний лише з дорогими курортами. Морський круїзний лайнер це своєрідне плавуче місце, яке приймає на свій борт від двохсот до 
шестисот туристів і стільки ж осіб обслуговуючого персоналу та членів екіпажу.

Програма круїзу визначає перелік всіх заходів, а також перелік послуг, що надаються туристам в морському круїзі. Підготовлена відповідним чином організатором круїзу програма круїзу повинна бути узгоджена із судновою адміністрацією, зокрема капітаном судна. Послуги туристам надаються відповідно до схваленої програми. Насамперед організатором круїзу може бути безпосередньо судновласник, тобто перевізник, який проводить круїз на певній лінії екскурсійне підприємство, або колектив підприємства, організації.

Відповідальний організатор круїзу укладає 3 перевізником договір про організацію круїзів на певну кількість рейсів, в тому числі на умовах фрахтування судна або на перевезення окремої групи відпочиваючих пасажирів. Значним символом круїзного флоту $\epsilon$ комфорт і комплексність ефективного обслуговування туристів та задоволення потреб усіх зацікавлених сторін.

На суднах рівень відповідного забезпечення туристів певними послугами може зрівнятися лише з найдорожчими курортами світу. Перелік заходів для досягнення цього на борті дуже різноманітний: кілька ресторанів, своя кухня, спортивні та оздоровчі заходи для різних вікових груп, індивідуальна обробка приміщень і меблів, пляж під час стоянок, різні розважальні програми, наявність казино, тематичні лекції, виставки, програми для дітей і підлітків.

Існують підприємства, які організовують спеціальні круїзи, які присвячені певній окремій професійній, цікавій чи будь-який інший тематиці. Розвиток туризму та спад, викликаний пандемією, призвело до необхідності поліпшення правового регулювання такої сфери туризму як річкові та морські круїзи.

В результаті цієї необхідності і з'явився такий різновид договорів як договір круїзу. Такий договір $€$ документом, який регламентує основні права і обов'язки перевізника і пасажира, а також інші питання, пов'язані з організацією і проведенням круїзу.

Таке докладне регулювання дуже зручно як перевізнику, так і пасажиру, бо кожен знає, які він має права і які несе обов'язки, що мінімізує кількість випадків взаємних претензій один до одного.

Наочною і зручною для турагентств і клієнтів $є$ цінова класифікація круїзів. Умовно їх можна класифікувати на п'ять категорій:

1) економічні (80-160 дол. США на людину в добу) виконуються на невеликих суднах старого зразка, які мають всі зручності великих лайнерів.

2) класичні (150-200 дол. США) круїзи превалюють на міжнародному ринку. Відбувається або на нових, або на переобладнаних суднах, які повністю відповідають сучасним вимогам по дизайну, комфорту та рівню сервісу: 3 просторими каютами, спортивними залами, басейнами, великими відкритими палубами, соляріями, салонами краси, магазинами, нічними клубами і казино.

3) преміум (200-400 дол. США) круїзи зосереджені на вибагливих клієнтах, які пред'являють якісніші вимоги до сервісу i комфорту. Таким туристам пропонується індивідуальне обслуговування 24/7.

4) люкс (400-1000 дол. США) призначені для дуже заможних туристів, які посідають високе становище в суспільстві. В першу 
чергу це своєрідні закриті клуби. Якість проявляеться майже в усьому: обслуговування по формулі ultra all inclusive («все включено»), кількість персоналу дорівнює кількості пасажирів, просторі каюти, інтер'єри, оформлені кращими дизайнерами, колекції дорогого живопису, персональна турбота про кожного пасажира. Географія круїзів цієї категорії тяжіє до екзотичних напрямків. Відпочинок на круїзних лайнерах класу люкс котирується вище відпочинку в будь-який фешенебельному готелі.

5) ексклюзивні круїзи (більше 1000 дол. США).

Відповідно до плати розрізняють певні системи організації круїзів: європейська, яка передбачає морську подорож із заходом у різні порти з екскурсійною програмою; американська, основною метою якої $є$ надання можливості круїзним пасажирам відпочивати і загоряти на пляжах в пунктах заходу по маршруту; «круїзи в нікуди» - одно- і дводобові поїздки без заходу в інші порти.

Круїзні рейси можуть бути організовані:

- безпосередньо судновласником. Туристичні агентства $€$ тільки посередниками і залучаються для організації реклами судна і рейса, розповсюдження квитків. Організація круїзу покладається на екіпаж судна, а судновласник несе експлуатаційні витрати і отримує всі надходження від роботи судна. Туристичні агентства в цьому випадку отримують комісійні від реалізованих квитків.

- фрахтувальником (в особі оператора, туристичних компаній) шляхом взяття судна в оренду.

При організації круїзів відносини, що виникають, між фірмоюоператором і підприємствами, які беруть участь в обслуговуванні туристів, оформляються відповідними договорами.

1. Договір із судновласником на оренду судів, який містить: кількість суден, їх назви і кількість місць за категоріями; маршрути круїзів і їх терміни; кількість білизни на один рейс для кожного судна і їх вартість; вартість оплати за кожен рейс; загальну вартість за договором за перевезення туристів; відповідальність сторін за договором.

2. Договір з рестораном на проведення організації харчування туристів на маршруті, який включає: перелік судів, відомості про кількість рейсів, тривалість одного рейсу, кількість туристів в рейсі, маршрут і вартість денного раціону харчування одного туриста 3 визначенням вартості набору продуктів; певні обов'язки компанії суднових ресторанів по виконанню взятих договірних обов'язків; порядок розрахунків за харчування; відповідальність сторін.

3. Договори 3 фірмами-організаторами, які займаються екскурсійним обслуговуванням туристів на визначеному маршруті. До цих договорів додається графік заходів в портах заходу 3 обов'язковим приведенням дат і термінів прибуття і програми обслуговування туристів і калькуляції, які включають: обов'язки туристично-екскурсійної організації; розробку тематики та відповідного проведення екскурсійних заходів.

4. Договір з музичним колективом, підприємством, яке буде займатися організацією дозвілля під час відпочинку у круїзному перевезенні.

Після проведення та укладання відповідних договорів, відбувається складання розкладу. При розрахунку елементів часу круїзного рейсу вкрай важливим $€$ встановлення необхідної 
тривалості стоянки в портах заходу, яка визначається туристичним характером пасажиропотоку. Величина ії буде значно більшою, ніж при виконанні звичайного пасажирского рейсу, оскільки час стоянки має бути достатнім для огляду туристами портового міста, знайомства з його визначними місцями тощо Тривалість стоянки в тому чи іншому порту буде залежати в цьому випадку від розміру міста, характеру його передмість та їх віддаленості від стоянки судна.

Розклад круїзних перевезень, як правило, складають на одиндва рейси, після чого вони змінюються. Це робиться 3 метою покращення попиту, а отже, і більшого завантаження суден. Але $\epsilon$ постійно діючі туристичні лінії.

Відповідно до програми і бюджетом часу рейсу встановлюються витрати і проводиться розрахунок вартості круїзу. Далі відбувається виготовлення програм, меню і путівок. Таким чином, робота по організації круїзних перевезень повинна починатися завчасно. Особливо це важливо при проведенні міжнародних рейсів в умовах пандеміï Covid-19, коли багато часу витрачається на встановлення контактів 3 різноманітними службами, зокрема, агентськими та туристичними фірмами і рекламування круїзу.

Реалізація турів при проведенні круїзних перевезень виробляють турагенти. Турагенції, в свою чергу, поділяються на дві категорії: організатори турів (tour - operators), посередницькі турагентства (intermediary travel agents).

Під час підписання угоди між судноплавною компанією і туристичним оператором на експлуатацію маршруту детально обумовлюється розклад руху судна і уточнюється план-карта судна.

План-карта круїзного судна - це розгорнута детальна схема 3 нанесеними пасажирськими приміщеннями (каюти, торгові кіоски, ресторани, басейни і т.п.) по кожній палубі окремо за допомогою відповідних умовних позначень, що $\epsilon$ загальноприйнятими в міжнародній практиці. План затверджується після виходу судна із дока.

Отже, тільки після укладення угоди туристичні організації отримують право почати реалізацію путівок. Путівка $є$ підставою для туриста зайняти на судні обумовлене місце та отримати комплекс послуг на протязі подорожі. На путівці вказують прізвище пасажира, назву судна, номер каюти і місце, порт відправлення і призначення, тариф, дату і час відправлення судна.

Організацією обслуговування пасажирів на борту судна займається екіпаж круїзного судна. Екіпаж круїзного судна складається 3 двох частин: команда судна і дирекція круїзу зі службою туристичного обслуговування. Екіпаж судна забезпечує на відповідному рівні управління судном, роботу всіх пристроїв і механізмів та їх своєчасне технічне обслуговування.

Працівники служб туристичного обслуговування виконують роботу 3 безпосереднього комфортного перебування туристів на судні під час подорожі. Головними обов'язками служби туристичного обслуговування є: проведення організації посадки і висадки туристів; розміщення туристів на судні; організацію доставки багажу туристів; проведення дозвіллєвих заходів з туристами; організацію збирання суднових приміщень для туристів; ведення документації, пов'язаної 3 перебуванням на борту туристів; організацію харчування туристів на судні; надання туристам побутових послуг; організацію роботи суднових магазинів і кіосків. 
Відповідальний за туристичну службу директор круїзу. Директор координує зусилля всіх служб, відповідає за оформлення всіх фінансових документів. На судах міжнародних компаній готельменеджер очолює туристичні служби, а директор круїзу відповідає тільки за дозвільну програму.

мати:

Під час проведення круїзу відповідальний керівник повинен

- $\quad$ копії угод про обслуговування туристів на борту;

- $\quad$ програми обслуговування в портах заходу;

- $\quad$ адреси і телефони фірм-партнерів;

- $\quad$ розрахунки вартості путівок за категоріями кают;

- посадові обов'язки працівників дирекції круїзу;

- $\quad$ комплексний план обслуговування туристів;

- шляхову інформацію;

- сценарії і матеріали проведення розважальних заходів;

заходу; доручення на підписання актів обслуговування в портах

\footnotetext{
туристичні книжки;

схему розташування кают даного судна;

розклад руху круїзного судна.
}

Склад дирекції залежить від виду круїзу, контингенту туристів (на судах типу «ріка море "дирекція включає 3-4 людини, на морських судах - 7-12 осіб і більше, в залежності від розміру судна), типу судна. Мінімальним $€$ штат дирекції круїзу, який складається з директора круїзу, готель-менеджера, директора ресторану і менеджера по дозвіллю.

Готель-менеджер відповідає за діяльність служб каютного обслуговування і побуту. У відповідності до цього служба каютного обслуговування забезпечує комплекс послуг, пов'язаних 3 проживанням туристів в каютах. Обслуговуючий каютний персонал складається з бортпровідників і стюардів. Служба побуту об'єднує персонал салонів-перукарень, масажних кабінетів, саун, хімчисток, магазинів тощо.

У обов'язки директора ресторану входить координація з питань надання послуг харчування. Иому підкоряються шеф, кухарі, офіціанти (стюарди), бармени, допоміжний персонал, що забезпечує роботу ресторану і барів.

У обов'язки менеджера по дозвіллю входить координація діяльності служби інформації, питань організації дозвілля і берегового обслуговування. Призначена служба дозвілля організовує відпочинок та розваги туристів протягом всього круїзу. Містить лектора, аніматорів, спортінструкторів, бібліотекаря, музикантів та ін. Чисельність працівників кожної служби визначається розмірами судна і кількістю туристів на кожному конкретному маршруті.

У відповідності до розподілених обов'язків програми перебування на судні поділяють на три види: щоденні - це стандартний набір послуг, який отримує клієнт; тематичні - це послуги, спрямовані на розширення реклами круїзів серед мандрівників з особливими інтересами в сфері розваг; освітні - це програми, які призначені для подорожуючих за спеціальними завданнями. 
Висновки і перспективи подальших досліджень у цьому напрямку. Аналіз організації круїзних перевезень за останні роки та акції круїзних компаній на світових біржах знизилися на 85-90\% за останні кілька місяців, і далі у великих компаній $є$ неприємна перспектива дійти до банкрутства.

Втрати найбільшого оператора круїзних суден Carnival Corporation PLC, який оперує флотом у 130 суден за 2 квартал 2020 становлять \$ 4,4 млрд. У інших компаній схожа ситуація, фінансові втрати призводять до звільнень берегового персоналу, зупинці і скасування контрактів на будівництва нових суден i, звичайно, продажу та утилізації вікового флоту [2].

Так, місяць тому було оголошено про продаж на злам всіх судів компаніï Pulman Tour (входить в холдинг Royal Caribbean Int). Компанія Carnival Corporation РІс продала 13 своїх судів різних брендів віком понад 15 років. Компанія Pulmantour Cruises здала на металобрухт два великих судна. Минулого тижня в 3МІ пройшло повідомлення, що Cruise \& Maritime Voyages (CMV) розорилася.

Відповідно зараз склалася унікальна ситуація на світовому круїзному ринку щодо можливості придбання круїзних суден відмінної якості за мінімальними цінами. Вартість деяких судів (місткістю 15002000 пасажирів) доходила на ринку до 10 млн євро.

Привабливість цін пояснюється і тим, що вартість металобрухту на світових ринках зараз також мінімальна, а круїзні компанії змушені продавати флот віком 15-20 років. В результаті зараз можна купити круїзні лайнери споруди 1990-2005 років за \$10-15 млн, або за 1015\% їх докризової вартості.

1. Про затвердження Сітература: України на період до 2038 року. Розпорядження Кабінету Міністрів України від11 лип. 2013 р. № 548-p. URL: www.kmu.ua.

2. The CEO of Carnival reveals the cruise industry's biggest challenge right now, Business Insider.

3. Кодекс торговельного мореплавства України. URL: http://zakon.rada.gov.ua/go/176/95-вp.

\section{References:}

1. Pro zatverdzhennja Strateghiji rozvytku morsjkykh portiv Ukrajiny na period do 2038 roku. Rozporjadzhennja Kabinetu Ministriv Ukrajiny vid11 lyp. 2013 r. \# 548-r. URL: www.kmu.ua.

2. The CEO of Carnival reveals the cruise industry's biggest challenge right now, Business Insider.

3. Kodeks torghoveljnogho moreplavstva Ukrajiny. URL: http://zakon.rada.gov.ua/go/176/95-vr.

In this article, we analyzed the organization of cruise traffic and existing problems and prospects for the development of cruise traffic in conditions of the pandemic Covid-19. At the present stage of development, there is a need to support and improve the mechanisms of state and international regulations of activities and the organization of cruises. The development of cruises, in general, depends on the 
effective organization of cruises in the conditions of the Covid-19 pandemic.

The main purpose of this work is to organize cruise shipments in the context of the Covid-19 pandemic based on the principles of international management and regulation.

Due to the restrictions associated with the Covid-19 pandemic, the summer season of 2020 proved to be very unattractive for the tourism industry, including clients of cruise companies. The previous season of 2019 turned out to be successful for international maritime operators. In the same year, the coronavirus caused severe damage to the industry. The season is not open yet and the future prospects are very vague. Currently, the entire tourism industry in the world is in a state of deep crisis due to the Covid-19 pandemic. World cruise shipping is experiencing the largest and most unprecedented crisis since World War II. This leads to record low prices in the secondary market of passenger ships, while for the last several decades, the sea cruise market has shown a significant increase and stable growth.

The international cruise market includes a very high concentration of fleets of a few cruise companies, that own almost $85 \%$ of the cruise market. Their offices are located across all countries of the world.

The Covid-19 pandemic came as a real shock to cruise operators, as this crisis has no analogues in the history of shipping in the last 70 years in terms of its global consequences.

Currently, most global cruise operators are owned by US companies (approximately $85 \%$ of the world's fleet) (Carnival Corporation PLC, Royal Caribbean International, NCL Cruise Holding), with the exception of MSC Cruises and a number of small regional operators registered in Europe. With the advent of the new Covid-19 virus in May 2020, US authorities banned cruise companies from accepting passengers for carriage from US ports. This led the entire fleet to the pier.

Analysis of the organization of cruise shipments in recent years and the shares of cruise companies on world stock exchanges have fallen by $85-90 \%$ over the past few months, and then large companies have an unpleasant prospect of bankruptcy. 